\title{
Integrated Crop Management - A Way for Doubling the Income of Tomato Growers in Ramanagara District of Karnataka, India
}

\author{
G. Keshavareddy ${ }^{1 *}$, S. Kamala Bai ${ }^{2}$, K. H. Nagaraj ${ }^{3}$ and B. G. Hanumantharaya ${ }^{4}$ \\ ${ }^{1}$ Department of Entomology, ${ }^{2}$ Department of Agronomy, \\ ${ }^{3}$ Department of Extension, ${ }^{4}$ Department of Horticulture, University of Agricultural Sciences, \\ GKVK, Bengaluru-560065, Karnataka, India \\ *Corresponding author
}

\begin{tabular}{|l|}
\hline K e y w o r d s \\
$\begin{array}{l}\text { Arka Rakshak, Triple } \\
\text { disease resistant, Front } \\
\text { Line Demonstration, } \\
\text { Doubling income }\end{array}$ \\
\hline Article Info \\
\hline $\begin{array}{l}\text { Accepted: } \\
\text { 20 May } 2018 \\
\text { Available Online: } \\
\text { 10 June } 2018\end{array}$ \\
\hline
\end{tabular}

\section{A B S T R A C T}

The front line demonstrations (FLD's) on Arka Rakshak F1 Hybrid of tomato were conducted by Krishi Vigan Kendra of Ramanagara District, Karnataka. Akra Rakshak, a triple disease resistant (bacterial wilt, early blight and leaf curl virus) hybrid was released by Indian Institute of Horticultural Research (IIHR), Bengaluru. Improved crop management practices were demonstrated in farmers field for three consecutive years from 2014-15 to 2016-17. As an outcome of FLD, it was noticed that the average per cent Bacterial wilt affected plants was low in demo plots $(1.4 \%)$ compared to farmer's practice plots $(14.43 \%)$ which was used as check. The timely plant protection measures along with marigold as trap crop reduced the average per cent fruits damaged by fruit borer in demo plots $(2.27 \%)$ compared to farmers practice $(11.70 \%)$. The per cent increase in fruit yield is 57.34 for the three years from demo plots over the farmer's practice. The other parameters like extension gap, technology gap and technology index were derived for the assessment of technology adoption rate. The average technology gap and technology index were 14.86 and 18.58 per cent respectively. The Benefit: Cost ratio of tomato cultivation during 2014-15, 2015-16 and 2016-17 under demonstrations were $4.11,4.13$ and 4.75 , respectively while it was $3.01,3.02$ and 3.73 under farmers practice for the respective years. The results clearly showed the positive impact of front line demonstrations over farmers practice towards increasing the productivity of tomato in Ramanagara district of Karnataka State. On an average $57.39 \%$ yield increase was observed in demo plots over farmers practice. Demonstrated technologies proved more remunerative and economically feasible to the tomato growers than their conventional methods. 


\section{Introduction}

The tomato (Solanum lycopersicum) is one of the most widely grown vegetable in the world (Ganeshan and Chethana, 2009). India is the second largest tomato growing country after China in area (8.65 lakh ha) and production (168.26 lakh tons) with an average productivity of $19.5 \mathrm{t} / \mathrm{ha}$ which is very low when compared to the other major tomato producing countries in the world. In India, tomato is the second most important vegetable crop, next to potato. Karnataka is the second largest producer after Andhra Pradesh (National Horticulture Board, 2011) with an average productivity of $34.3 \mathrm{t} / \mathrm{ha}$ which is much higher than national average. The tomato is known for its nutritive value and combined in many different dishes and eaten in different ways as a fresh vegetable or made into soup or sauce. It is a low calorie vegetable, low in fat, has no cholesterol and is an excellent source of anti-oxidants, dietary fiber, minerals, potassium and vitamins. Eating tomatoes has been promoted as helping to prevent some human diseases (cancer and heart diseases) and improving the immune system response (Ntonifor et al., 2013). Tomato is considered as commercial vegetable crop in Ramanagara district in recent years, which is an adjacent district of Bengaluru. It is one of the main district of Karnataka where tomato is widely grown in all the four taluks viz., Magadi, Ramanagara, Kanakapura and Channapatna. Tomato is of great importance to the small and marginal farmers in the district in terms of income generation and local consumption but majority of tomato growers are not aware of improved and ecofriendly cultural practices.

Apart from biotic stress, soil health conditions and fertility status selection of variety by the farmers also play an important role in obtaining higher yields. Analysis of soil samples of selected farmers in cluster villages in Magadi and Channapatna Taluks revealed that most of the soils were low to medium in organic matter content and all the samples are deficient in calcium, magnesium, boron, zinc nutrients which leads to poor crop stand. Due to calcium deficiency blossom end rot is very severe during summer and kharif seasons. Arka Rakshak a triple disease resistant variety was developed by the Indian Institute of Horticultural Research (IIHR). This variety produces medium to large (80-100g) deep red, very firm fruits with good keeping quality (1520 days). The potential yield of the hybrid is $90 \mathrm{t} / \mathrm{ha}$.

The major problems that the farmers facing in tomato cultivation are plant protection related problems. Among insect pests, Fruit borer, Helicoverpa armigera and Leaf miner, Liriomyza trifoli are the major insect pests. The major diseases noticed are Bacterial wilt, Fungal wilt, early \& late blight and leaf curl diseases. Late blight is very predominant during November to February months and bud necrosis \& leaf curl in summer. Most of the tomato cultivators in the district lack knowledge about specific insecticides/fungicides/bactericides or integrated pest and diseases management practices for management of the above said insect pests and diseases. The productivity of tomato is only 35 to $40 \mathrm{t} / \mathrm{ha}$ in the district (Department of Horticulture and crops statistics, Govt. of Karnataka, 2011). With this back ground, KVK, Ramanagara conducted Front Line Demonstrations (FLD's) to show the worth of high yielding and triple disease resistant Arka Rakshak F1 hybrid to the 10 selected tomato growers each year during 2014-15, 2015-16 and 2016-17 on cluster villages concept basis in the district.

\section{Materials and Methods}

Soil samples of selected farmers' fields where FLDs were planned to be conducted were 
analyzed and based on the results, improved agronomic practices viz., recommended quantity of manures (FYM-25t/ha) and correct dosage of fertilizers (180:120:150 kg NPK) were demonstrated. Soil application of FYM enriched with Trichoderma viridae was demonstrated to combat soil borne diseases. For the purpose of FLD's, a high yielding and triple disease resistant hybrid Arka Rakshak was newly introduced to the selected farmers in the district. Arka Rakshak was known to resistant to leaf curl virus, bacterial wilt and early blight disease. Normally farmers grow local tomato varieties and the same varieties were used as check during front line demonstrations. To supplement micro nutrients, foliar sprays of vegetable special developed by IIHR, Bengaluru @ 4 g per liter of water was demonstrated. For every 20 liters of water $80 \mathrm{~g}$ of vegetable special + one lemon juice +1 sachet shampoo were mixed and sprays were taken. To combat calcium $(\mathrm{Ca})$ deficiency, foliar spray of CAN (Calcium Ammonium Nitrate) @ 5g per liter of water at an interval of 15 days was demonstrated. To reduce the incidence of fruit borer (Helicoverpa armigera) one row of African giant marigold was transplanted after every 16 rows of tomato. Drip irrigation for effective water conservation and mulching for effective weed management were also demonstrated. As part of integrated pest management practices, yellow sticky traps @ 25 per hectare were erected for monitoring thrips and white flies infestation. To control fruit borer, when the larvae is at early stage spray with HaNPV @ $250 \mathrm{LE} / \mathrm{ha}$ was demonstrated.

As a mandated activity, KVK had undertaken Front Line Demonstrations of Arka Rakshak cultivation demonstrating Integrated Crop Management (ICM) practices in 30 farmers field during 2014-15, 2015-16 and 2016-17. On-farm testing related to fertigation schedule in cultivation of Arka Rakshak covering five farmers was also conducted to re-confirm the performance of fertigation schedules. In order to reach more number of tomato growers to disseminate improved technologies, several other educational activities were also conducted by KVK, Ramanagara as part of capacity building activities.

The data on various parameters were carefully recorded from demo and farmers practice (check) plots. Number of plants affected by bacterial wilt, fungal wilt, late blight incidence and fruits damaged by fruit borer were recorded. The leaf miner infestation was recorded by visual observations on the basis of area of leaves damaged by leaf miner. For this self-designed miner damaged scoring scale 04 was used. Where $0=$ no infestation, $1=1$ $10 \%, 2=11-25 \%, 3=26-50 \%$ and $4=51-$ $100 \%$ leaf area damaged. The per cent increase in yield was calculated by using the following formulae.

Fruit yield under demo plot Fruit yield under farmer's practice Per cent increase in yield = ------------ X 100

Fruit yield under farmer's practice

The Extension gap, Technology gap and Technology index, Benefit Cost ratio were worked out by the following formulae as per Samui et al., (2000).

Extension gap $=$ Demonstrated plot yield Farmers practice plot yield

Technology gap = Potential yield Demonstrated plot yield

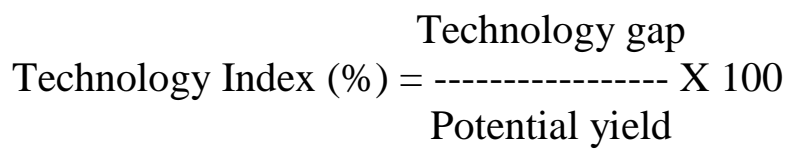

\section{Results and Discussion}

The results of the pooled data of frontline demonstrations for three years (2014-15, 
2015-16 \& 2016-17) are presented in Table 1. The bacterial wilt, fungal wilt, late blight incidence and tomato fruits damaged by fruit borer were expressed in per cent plants affected or fruits damaged. The average bacterial wilt affected plants was lowest (1.4\%) in demo plots where Arka Rakshak was grown compared to the farmers practice $(14.43 \%)$. Since Arka Rakshak is triple disease resistant (bacterial wilt, early blight and leaf curl virus) F1 hybrid, lowest average per cent of plants affected by bacterial wilt were observed in demo plots. The highest average per cent bacterial wilt affected plants in the farmers practice was recorded in Srigiripura cluster village of Magadi Tq. The soils of Srigiripura and surrounding villages are bacterial wilt sick soils. Specially, when farmers grow solanaceous crops like brinjal, potato, chilli and tomato. They will be under great loss due to severe bacterial wilt incidence when the crops are at flowering and fruit bearing stage. The average per cent plants affected by fungal wilt were high $(4.37 \%)$ in farmers practice compared to demo plots $(1.47 \%)$. The wilt affected plants average per cent in demo plots was low since farm yard manure (FYM) enriched with Trichoderma viridae was applied to the soils at the time of seedlings transplantation. Trichoderma is known to suppress many soil borne fungal diseases under given favorable soil conditions. The average per cent of plants affected by late blight is very low in demo plots compared to farmers practice plots $(15.44 \%)$. The front line demonstrations were took during rabi season. Usually during the months of October to January, weather conditions would be favourable for late blight occurrence. However, late blight incidence was low in demo plots since prophylactic and curative measures, fungicides sprays were taken.

The average per cent fruits damaged by fruit borer in demo plots was very low (2.27) compared to farmers practice (11.70). Timely spraying of Ha NPV @ 250 LE/ha in demo plots and growing African Giant Marigold as trap crop in demo plots reduced the fruit borer damage. Further fruit borer is the major insect pest in tomato and need based right plant protection measures both on trap crop and main crop resulted in low damage and higher yields. Picking and selling marigold flowers once in 3-4 days also helps in reduction in fruit borer incidence since Helicoverpa moths prefers to lay eggs on African marigold flowers.

The average leaf miner incidence was comparatively high in farmers practice plots (2.13 score) based on 0-4 scale scoring basis than demo plots (1.34 score). This might be due to the timely spraying of specific insecticides with correct dosage for the management of leaf miner.

The results clearly indicated that the number of fruit pickings were more (17) in demo plots (Table 1) compared to farmers practice (12 pickings). This was mainly due to integrated pest and diseases management (IPDM) practices adopted by the farmers. Integrated pest and disease management practices helps in plant health management by reducing number of sprays required to control pests and diseases. Only 11 sprays were undertaken in demo plots as comparted to 17 sprays in the farmers practice.

Based on the observations made during front line demonstrations, Extension gap, technology gap and Technology index were worked out. The Extension gap is the difference between demonstrated plot fruit yield and farmers practice plot (check) fruit yield. The highest extension gap observed was 24.87 t/ha (Table 2) in the year 2014-15, followed by $23.65 \mathrm{t} / \mathrm{ha}$ (2015-16) and 22.70 t/ha (2016-17). On an average the extension gap observed during three years in FLDs implemented villages was $23.74 \mathrm{t} / \mathrm{ha}$. 
Table.1 Effect of frontline demonstration versus check on pest control and Yield parameters of tomato

\begin{tabular}{|l|c|c|c|}
\multicolumn{1}{|c|}{ Parameters } & Check & Demo & \% change over \\
\hline Bacterial wilt (\%) & 14.43 & 1.4 & -90.29 \\
\hline Fungal wilt (\%) & 4.37 & 1.47 & -66.36 \\
\hline Late blight (\%) & 15.44 & 5.37 & -65.22 \\
\hline Fruit borer damage (\%) & 11.70 & 2.27 & -80.60 \\
\hline Leaf miner incidence (scale 0-4) & 2.13 & 1.34 & -37.09 \\
\hline No. of pickings (Av. of 30 demos) & 12 & 17 & 41.67 \\
\hline Avg. No. of sprays (Pesticides & 17 & 11 & -35.29 \\
\hline sprays) & & & 51.40 \\
\hline Yield (t/ha) & 161167 & 190167 & 17.99 \\
\hline Gross cost (Rs./ha) & 523083 & 822690 & 57.27 \\
\hline Gross Income (Rs./ha) & 361917 & 632523 & 74.77 \\
\hline Net income (Rs./ha) & 3.25 & 4.33 & - \\
\hline B:C ratio & & & \\
\hline
\end{tabular}

Table.2 Technological gap, Extension gap and Technology Index in Arka Rakshak tomato Cultivation

\begin{tabular}{|c|c|c|c|c|c|c|c|}
\hline \multirow[t]{2}{*}{ Year } & \multirow{2}{*}{$\begin{array}{l}\text { Potential } \\
\text { yield } \\
(t / h a)\end{array}$} & \multicolumn{2}{|c|}{ Average yield (t/ha) } & \multirow[b]{2}{*}{$\begin{array}{c}\text { Increase } \\
\text { in yield } \\
\text { over } \\
\text { farmers } \\
\text { practice } \\
(\%)\end{array}$} & \multirow{2}{*}{$\begin{array}{c}\text { Extension } \\
\text { Gap } \\
(\text { t/ha })\end{array}$} & \multirow{2}{*}{$\begin{array}{c}\text { Technology } \\
\text { Gap } \\
(\text { t/ha })\end{array}$} & \multirow{2}{*}{$\begin{array}{c}\text { Technology } \\
\text { Index } \\
(\%)\end{array}$} \\
\hline & & $\begin{array}{l}\text { Farmers } \\
\text { practice } \\
\text { (check) }\end{array}$ & $\begin{array}{c}\text { Demonstrated } \\
\text { plot }(F L D)\end{array}$ & & & & \\
\hline 2014-14 & $80 \mathrm{t} / \mathrm{ha}$ & 43.45 & 68.32 & 57.23 & 24.87 & 11.68 & 14.60 \\
\hline $2015-16$ & $80 \mathrm{t} / \mathrm{ha}$ & 39.20 & 62.85 & 60.33 & 23.65 & 17.15 & 21.44 \\
\hline 2016-17 & $80 \mathrm{t} / \mathrm{ha}$ & 41.55 & 64.25 & 54.63 & 22.70 & 15.75 & 19.69 \\
\hline Mean & $80 \mathrm{t} / \mathrm{ha}$ & 41.40 & 65.14 & 57.39 & 23.74 & 14.86 & 18.58 \\
\hline
\end{tabular}

Table.3 Comparison of Economics of Tomato Hybrid Arka Rakshak over Farmers Practice

\begin{tabular}{|c|c|c|c|c|c|c|c|c|}
\hline Year & $\begin{array}{c}\text { Cost of cultivation } \\
\text { (Rs.) }\end{array}$ & \multicolumn{2}{|c|}{$\begin{array}{c}\text { Gross return } \\
\text { (Rs.) }\end{array}$} & \multicolumn{2}{|c|}{$\begin{array}{r}\text { Net return } \\
\text { (Rs.) }\end{array}$} & \multicolumn{2}{|c|}{$\begin{array}{r}\text { B:C ratio } \\
\text { (Rs.) }\end{array}$} \\
\hline $\begin{array}{l}\text { Farmers } \\
\text { practice }\end{array}$ & Demo & $\begin{array}{l}\text { Farmers } \\
\text { practice }\end{array}$ & Demo & $\begin{array}{l}\text { Farmers } \\
\text { practice }\end{array}$ & Demo & $\begin{array}{l}\text { Farmers } \\
\text { practice }\end{array}$ & Demo \\
\hline $\mathbf{2 0 1 4 - 1 5}$ & 158500 & 183000 & 477950 & 751520 & 319450 & 568520 & 3.01 & 4.11 \\
\hline $\mathbf{2 0 1 5 - 1 6}$ & 169000 & 198000 & 509600 & 817050 & 340600 & 619050 & 3.02 & 4.13 \\
\hline $\mathbf{2 0 1 6 - 1 7}$ & 156000 & 189500 & 581700 & 899500 & 425700 & 710000 & 3.73 & 4.75 \\
\hline Mean & $\mathbf{1 6 1 1 6 7}$ & $\mathbf{1 9 0 1 6 7}$ & $\mathbf{5 2 3 0 8 3}$ & $\mathbf{8 2 2 6 9 0}$ & $\mathbf{3 6 1 9 1 7}$ & $\mathbf{6 3 2 5 2 3}$ & $\mathbf{3 . 2 5}$ & $\mathbf{4 . 3 3}$ \\
\hline
\end{tabular}


Table.4 Extension Activities Carried out by KVK to Educate Tomato Growers of Ramanagara District from 2013-14 to 2016-17

\begin{tabular}{|c|c|c|c|}
\hline $\begin{array}{l}\text { Sl. } \\
\text { No. }\end{array}$ & Methods & $\begin{array}{l}\text { Number / } \\
\text { Programs }\end{array}$ & $\begin{array}{l}\text { No. of } \\
\text { farmers } \\
\text { reached }\end{array}$ \\
\hline 1 & Group discussions & 16 & 193 \\
\hline 2 & On Farm Testing (OFT) & 1 & 5 \\
\hline 3 & Front Line Demonstrations (FLD's) & 3 & 30 \\
\hline 4 & Training programmes (On \& Off campus) & 13 & 389 \\
\hline 5 & Field days conducted & 5 & 142 \\
\hline$\overline{6}$ & $\begin{array}{l}\text { Farmers personal visit to KVK for advisory services } \\
\text { about tomato problems (since 2014) }\end{array}$ & 138 & 138 \\
\hline 7 & Advisory service through Whats App (since 2014) & 172 & 172 \\
\hline 8 & Method demonstrations conducted at KVK & 19 & 217 \\
\hline 9 & $\begin{array}{l}\text { News coverage about Integrated Crop Management } \\
\text { in Tomato: } \\
\text { a) TV programmes } \\
\text { b) Local news papers }\end{array}$ & $\begin{array}{c}1 \\
13\end{array}$ & - \\
\hline 10 & $\begin{array}{l}\text { Literature distribution (regarding tomato) } \\
\text { a) Folders } \\
\text { b) Leaf lets }\end{array}$ & $\begin{array}{c}1000 \\
500\end{array}$ & $\begin{array}{c}1000 \\
500\end{array}$ \\
\hline 11 & Farmers Field School (FFS) & 1 & 25 \\
\hline 12 & $\begin{array}{l}\text { Agriculture Short Message Service (ICT } \\
\text { Application) }\end{array}$ & 23 & 5925 \\
\hline 13 & Cell phone calls & 204 calls & 204 \\
\hline 14 & Exposure visits & 7 & 183 \\
\hline
\end{tabular}

Krishi Vigyan Kendra bridges the extension gap between the technologies developed at the research institutions or State Agriculture \& Horticulture Universities and its adoption at the field level by the farmers through various extension approaches (Table 4). KVK adopted cognizance approach where 16 group discussion meetings regarding tomato cultivation were conducted covering 193 farmers. The other cognizance approaches were news coverage (1 TV programme- ETV Kannada, Annadatha Programme \& 13 local newspapers coverage) and distribution of extension literature (folders-1000 no.s \& leaf lets -500 no.s). As a tool of ICT, KVK has implemented Agriculture Short Message Service (ASMS). From 2013 to 2017, 23
SMSs related to tomato cultivation were sent covering 5925 farmers. Apart from the cognizance approach and ICT tool, methodological approaches are the main stay of KVK to up-scale technologies to the farmers. Three front line demonstrations (30 demos), one On-farm Testing (OFT), 13 training programmes (On \& Off trainings) covering 389 farmers and 5 field days covering 142 farmers were conducted. Above various extension methods mainly focused on introduction of Arka Rakshak, a triple disease resistant high yielding F1 hybrid cultivation. Higher extension gap emphasizes that there is a need to educate tomato growers for adoption of improved production technologies and integrated pest and diseases management 
practices like African giant marigold as trap crop for tomato fruit borer, soil application of farm yard manure enriched with Trichoderma, erection of sticky traps, vegetable special sprays, application of fertilizers based on soil test results and spraying of proper plant protection chemicals at right dose and right time to combat pests and diseases during cropping period. Subsequently conventional tomato cultivation practices may be replaced by improved technologies thus reversing the trend of wide extension gap.

Technology gap is the difference between potential yield and demonstrated plot fruit yield. The results indicated a technology gap of $11.68,17.15$ and 15.75 t/ha during 201415, 2015-16 and 2016-17 respectively. The average technology gap for 3 years when FLDs were implemented is $14.86 \mathrm{t} / \mathrm{ha}$. The technology gap observed may be attributed to dissimilarities in the physical, chemical and biological soil status and local climatic conditions prevailed when front line demonstrations implemented during 2014 to 2017. Lower the value of the technology gap, more is the feasibility of the technologies which could be easily adopted by the farmers as they are user friendly.

Technology index shows the feasibility of evolved technology at the farmer's fields. The technology index varied from 14.60 to 21.44\% (Table 2). An average Technology index observed was $18.58 \%$ for three years. This shows efficiency and effectiveness of the improved technologies as a result of successful technical interventions. Thus achieving higher yields nearest to potential yields will accelerate the adoption of demonstrated technical interventions to increase the tomato yield.

The input and output prices of commodities prevailed during the study periods and their economic returns were recorded. The cultivation of tomato under improved technologies (FLD's) gave higher net returns of Rs. 568520, Rs. 619050 and Rs. 710000/ha as against to the farmers practices i.e., Rs. 319450 , Rs. 340600 and Rs. 425700 per hectare during 2014-15, 2015-16 and 2016-17 respectively (Table 3). Similar results were corroborated with Raj et al., 2013 and Singh et al., 2014 findings. The Benefit: Cost ratio of tomato cultivation during 2014-15, 201516 and 2016-17 under improved cultivation practices were $4.11,4.13$ and 4.75 , respectively while it was $3.01,3.02$ and 3.73 under farmers practice for the respective years. The higher net return in demo plots is attributed to higher yields due to reduction in per cent death of plants due to bacterial and fungal wilts, reduction in per cent fruit damage due to fruit borer and increase in number of fruit pickings. More number of fruit pickings in demo plots was mainly because good plant health management by adopting integrated nutrient and pest and diseases management practices. Adoption of correct dosage and specific chemicals and their timely spays for specific problems also reduced the cost of cultivation. The higher Benefit: Cost ratio in demo plots is because of higher yields obtained under improved technologies compared to farmer's practices during all the three years. These results are in corroboration with the findings of Mokidue $e t$ al., (2011).

The study revealed lack of knowledge among tomato growers about disease resistant and high yielding tomato hybrids \& their nonavailability, maintaining optimum spacing between the plants, importance of balanced nutrients application and role of micro nutrients in quality fruits production, benefit of planting marigold as trap crop in tomato and timely plant protection measures to combat pests and diseases. The high productivity in demonstration plots over 
farmers practice (check) created awareness among the tomato growers and motivated other farmers to adopt appropriate improved production and protection technologies in tomato cultivation. In order to up-scale the technologies demonstrated by Krishi Vigyan Kendra, there is a need for collaborative efforts from all the stake holders including Department of Horticulture, Indian Institute of Horticultural Research and Farmers Producer Organisations

\section{References}

Ganeshan, G. and Chethana, B. S. 2009. Bioefficacy of pyraclotrobin 25\% EC against Early Blight of tomato. World App. Sci. J. 7: 227-229

Mokidue, I., A. K. Mohanty and Sanjay, K. 2011. Correlating growth yield and adoption of Urdbean technology. Indian. J. Extn. Edu. 11(2): 20-24

National Horticulture Board. 2011. Indian Horticulture Database. Pp. 296
Ntonifor, N. N., D. N. Nsobinenyui, E. B. Fokam and Fontem, L. A. 2013. Developing an integrated management approach for the fruit fly Dacus punctatifrons on tomatoes. American J. Expt. Agri. 3: 470-481

Raj, A. D., V. Yadav and Rathod, J. H. 2013. Impact of Front Line Demonstration on the yield of Pulses. Int. J. Sci. Res. Public. 3(9): 2250-2254.

Samui, S. K., S. Maitra, D. K. Roy, A. K. Mandal and Saha, D. 2000. Evaluation of front line demonstration on groundnut. J. Indian Soc. Coastal Agril. Res. 18(2): 180-183.

Singh, D., A. K. Patel., S. K. Baghel, M. S. Singh, A. Singh and Singh, A. K. 2014. Impact of Front Line Demonstration on the Yield and Economics of Chickpea in Sindhi District of Madhya Pradesh. $J$. Agril. Res. 1(1): 22-25.

\section{How to cite this article:}

Keshavareddy G., S. Kamala Bai, K. H. Nagaraj and Hanumantharaya B. G. 2018. Integrated Crop Management - A Way for Doubling the Income of Tomato Growers in Ramanagara District of Karnataka, India. Int.J.Curr.Microbiol.App.Sci. 7(06): 2161-2168. doi: https://doi.org/10.20546/ijcmas.2018.706.256 